\title{
SPECIFICITY OF OPERATION OF GENERAL INTEREST IN THE SERBIAWITH SPECIAL VIEW ON WATER MANAGEMENT
}

\author{
Ljiljana Rajnović ${ }^{1}$ \\ *Corresponding author E-mail: rajnoviclj@gmail.com
}

\begin{abstract}
A R T I C LE IN F O
A B S T R A C T

Review Article

Received: 09 March 2020

Accepted: 11 May 2020

doi:10.5937/ekoPolj2002537R

UDC 336.61:556.18(497.11)

In this paper, the author presents the specificities of economic entities performing activities of general interest. In the Republic of Serbia, the state is responsible for the regulating of organized and permanent performance and the development of activities of general interest. In Serbia, the state ensures performing this activity through public companies or capital companies of which it is

Keywords:

activities of general interest, specificity activities, users of services, safety of performing activities, supervision. the sole founder, but it is possible to allow performing the aforementioned activities by entrusting them to a third party. The author conducted a survey related to the necessary conditions for performing activities of general interest by entrusting to a third party a few dozen of economic entities in Serbia. The author considers that, JEL: $Q 14$ with fulfillment of prescribed conditions, the successful performing activities of general interest can be carried out by privately owned economic entities, since state-owned enterprises have proved to be insufficiently efficient and economical in practice.
\end{abstract}

(C) 2020 EA. All rights reserved.

\section{Introduction}

Activities of general interest are part of an economy that is in many ways different from traditional market activities. The fact that, as a rule, no competition is introduced into these activities (often not even possible, especially in non-profitable industries), places activities of general interest in some form of monopoly position. A specialty of the activities of general interest is that this monopoly is also controlled through the status of the companies themselves (control of functions by the founder) and by direct control of the prices of services of general interest. All activities of general interest have the common feature that they represent an indispensable condition for the life and work of citizens.

The state is obliged to ensure the continuous performance of activities of general interest, and about that, the economic entities that perform mentioned activity have the same obligation, because it is a very important function for each state and society as a

1 Ljiljana Rajnović Ph.D., Institute of Agricultural Economics, Belgrade, Volgina 15, Phone: + 381 63273 237, E-mail: rajnoviclj@gmail.com, ORCID ID (https://orcid.org/0000-0002-8209-9088) 
whole, have a great impact on the community, so they have an obligation to act in the general social interest (Corbett, 2008), respecting the good rules of socially responsible business. In the case of disruption in the performance of these activities, the state is obliged to take measures that will provide conditions for the smooth performance of activities of general interest. Property solutions in this sector based on public property, are undeniably effective in preventing private monopoly, and as the convenience of such a solution is the fact that state can effectively manage the development of technical systems in a particular area, which allows them to effectively implement different development policies. A solution like this, at least in principle, can provide high security of supply, respectively the regularity of providing services of general interest. It is clear that the state cannot go bankrupt, so there is no risk of disruption of business activity due to the financial difficulties of the operator.

On the other hand, a property solution like this implies lower efficiency of performing the mentioned activities, low possibilities for financing investments in the development of these activities, a greater burden on the competent budgets, and also provides opportunities for the appearance of some more negative side effects. This property or organizational solution is being implemented in Germany and the Scandinavian countries, ie. countries with strong government and secure funding.

The obligation of the state to provide the citizens with the most optimal living and working conditions in the territory, determined, of course, by the overall level of diversity, in the field of economic and social development, will not be excluded, regardless of the ownership status of the enterprises engaged in activities of general interest. The issue of responsibility for the functioning of infrastructure of an activity of general interest through ensuring continuity, quality, scope and development cannot be left to anyone else. This is one of the basic obligations, rights and responsibilities of the state.

Higher level of development of the country's economy is accompanied by diversification of activities of general interest, their increasing number and better quality (more frequent washing of streets, more frequent removal of garbage, better quality of water, better water, better urban and suburban transport, etc.). Agriculture is the main economic sector which depends to a considerable extent on the natural situation (Vasilescu et al., 2010). The thermal solar potential can be reached if technologies are being advertised for institutions that have a high consumption of warm water and heat (Dusmanescu et al., 2014).

The state, the Republic of Serbia (RS), the Autonomous Province (AP) and local selfgovernment units (LSGU) are competent for a wide range of activities of general interest, including public utilities. According to the provisions of the Law on Public Enterprises (LPE) and the Law on Local Self-Government, the regulation of organized and permanent performance and development of activities of general interest, respectively public utilities, are the responsibility of the state. The state is obliged to provide the organizational, material and financial conditions for providing these services to end 
users. Business entities that performing activities of general interest have their assets by which they are liable for their obligations, and they should operate independently, financially transparently and on an equal footing with other companies in the market. If the general interest requires that the prices of services or products of business entities that performing an activity of general interest, must be formed at a non-market level, the state will be obliged to provide the budget with funds for that amount and to disclose it.

According to the provisions of the LPE, activities of general interest are activities defined as such by law in the fields of: mining and energy, transport, electronic communications, publishing of the official gazette of the Republic of Serbia and publishing of textbooks, nuclear facilities, weapons and military equipment, utilization, management, protection, landscaping and promotion of goods of general interest and goods of general use (water, roads, forests, navigable rivers, lakes, coasts, spas, game, protected areas, etc.), waste management, scientific research, public utilities, as well as other activities defined by law as activities of general interest.

There are several hundred state-owned enterprises in the Serbian economy. These include public companies of republic (JP EPS, JP Srbijavode, JP Srbijagas) and capital companies, Elektromreza ad, Telekom Srbija ad, etc, several public companies founded by an autonomous province, local public utilities (water and sewerage, garbage collection), but also companies that do not perform activities of general interest, do not have a special status, but compete with others on the market (until recently RTB Bor, Dunav osiguranje ad, Expert Bureau Novi Sad, JRB ad Belgrade, etc.).

\section{Business entities responsible for public interest activities - solutions in some countries}

Activities of general interest in France are conducted by economic entities constituted in the form of public institutions with industrial or commercial character or in the form of companies of capital, as well as public enterprises of national or local importance, and companies with public capital incorporated by the state or which are nationalized and mixed-capital companies of national or local character (Dufau, 1973).

Public sector activities in England, such as gas, water, rail, electricity, infrastructure, etc. were performed by companies established by state-owned law.

Most of these companies were later privatized, and those that remained in state property are most often entrusted with the concession agreement to privately owned companies and precisely specifies the rights and obligations of the contracting parties, with special reference to the need for continuously conducting this activity and satisfaction of needs of service users, as significant target functions of these companies, in addition to, of course, the primary function, earning profit (Gower, 1992).

In Germany and the Scandinavian countries, activities of general interest are performed predominantly through entities established by the state.

Thus, the performance of the activity of the general interest may be carried out directly 
by the state, or by the establishment of economic entities for the purpose of performing the mentioned activity, as follows:

- the establishment of a capital company by the state through law (for example: in the field of water, rail transport, scientific research, production, processing and marketing of oil and natural gas, electricity, mail, etc.) in which case the state appears as a single owner, a shareholder or stakeholder, depending on the form in which the company is founded (Hamel \& Lagarde \& Jauffret, 1980),

- performing public utilities, production and delivery of water, gas, heat, maintenance of streets, roads, public areas of cleanliness, funeral services, public transportation of passengers in settlements, waste water treatment and disposal, etc. establishment of a capital company by decisions of territorial units (republic, province, district, city, municipality) (Hamel \& Lagarde \& Jauffret, 1980),

- direct performance of the activity through public services by the state or territorial unit (whereby these entities do not acquire the capacity of a trader) (Hamel \& Lagarde \& Jauffret, 1980),

- establishment, the so-called public corporation (our term "public corporation" corresponds to "statutory company" or "chartered company" - in English law, or "public", a corporation founded by a state or territorial unit in U.S. law, and the term "open corporation" corporations established by public registration of capital, joint stock companies) and communal enterprise as existing forms that will gradually be transformed into privately owned companies by privatization,

- then, nationalization, which is less and less represented in modern marketoriented countries, of certain private companies that the state finds interested in (banks, insurance organizations) by paying a fee in cash or bonds and preserving the form of capital company (and the commercial character of its business) a nationalized company (banks, insurance organizations, of which the sole member is the state) (Hamel \& Lagarde \& Jauffret, 1980).

In addition, contractual and / or equity relations in area of activities of general interest may be pursued as follows:

- concluding a concession contract by a state with a legal or natural person, by which the concessionaire gives to the concessionaire for a limited time a right to use, manage and perform a public service, at his own risk ("exclusive right of use"), with the obligation to protect the public interest and payment of the agreed usage fee(Hamel \& Lagarde \& Jauffret, 1980),

- by setting up joint ventures of capital (with state capital and / or with capital of territorial units and private capital).

- transformation of state-owned or nationally-owned companies into stateowned joint ventures in the aftermath of privatization (most often also with so- 
called "workers' actions" and with the use of a special type of action - so-called golden shares - eg SNCF, Air France, etc.) (Hamel \& Lagarde \& Jauffret, 1980).

Public, state owned companies perform activities of general interest in the territory of the Republic of Serbia.

A public company is enterprise that performs an activity of general interest, established by the RS, an AP or a unit of LSGU, in order to perform that activity.

In addition to a public company, an activity of general interest may also be performed by:

- a limited liability company and a joint stock company whose sole owner is a public company,

- a capital company whose sole owner is the Republic of Serbia, an autonomous province, a unit of local self-government, as well as a subsidiary whose sole owner is that capital company,

- another capital company and an entrepreneur, entrusted by the competent authority with the performance of that activity, respectively an economic entity in private or other ownership, which fulfills the conditions for performing an activity of general interest (Law on Public Enterprises).

According to the provisions of the law which edit position of public enterprises, public enterprises and capital companies specified in the law, are established and they operate for the purpose of:

- $\quad$ ensuring permanent performing of activities of general interest and regularly satisfaction of needs of users of products and services

- development and promotion of activities of general interest,

- $\quad$ ensuring the technical, technological and economic unity of the system and the coherence of its development,

- gaining profit and

- $\quad$ pursuing another legally established interest.

\section{Confidentiality of operating activities of general interest}

The time of the 1990s and the beginning of this century in the countries of Western Europe was marked mainly by the privatization of the public sector of the economy. The state is gradually withdrawing from the economic function, since as an entrepreneur, it cannot compete with a private entrepreneur, given its many other functions. This applies not only to the commercial sector of the economy, but increasingly to the activities of general interest, that is, the public sector. Increasingly, the state reserves the right to prescribe market game rules for market participants and to ensure strict enforcement of their application, both privately and publicly. It is much more important for the state to have good taxpayers than to have state-owned companies operating at a loss and having 
to deal with it continuously and comprehensively. In general terms, well - managed societies contribute to the domestic economy and in same time community, and to pay attention on providing greater profits, to strengthen investor confidence in the domestic market (Berber, Slavić, Aleksić, 2019).

To the extent that it remains in economic function, the state is increasingly forced, due to budget deficits and inefficiencies of the public sector, to abandon the position of exclusive ownership in public sector activities, both at national and territorial units. In such a situation, begin to form capital companies, joint stock companies and limited liability companies which are performing these activities. If for some reason the state has to remain the sole owner of some companies which performing activities of general interest (investor is not interested in privatization, securing competition before privatization - experience shows that the natural monopoly sector requires privatization before privatization - introducing competition, as one monopoly - state would not replace another monopoly - private, which is more dangerous and more difficult to resolve) then the state is obliged to ensure their equal position on the market entity and transparency of financial business (Vasiljević, 1999).

To the extent that it remains in the economic function, the state has an interest in transforming that business entity into a joint stock company, because of the highest mobility of that capital. If the state is a shareholder, in principle it has a position in a joint-stock company like all other shareholders: profit and management is commensurate with capital. However, in case of activities for which is determined by law to have a public interest, then the state or a narrow territorial unit may also acquire special rights in the capital companies which perform that activity, and even if in those entities they have a minority share capital or no capital.

This is especially important from the point of view of the need for ensuring the permanency and continuity of the performance of these activities, as well as the equal treatment of users of services in that activity. Special rights of the state can be acquired in the process of privatization of public sector enterprises, when it can retain a special type of shares - the so-called a golden share, which grants it a majority right to decide, in which case, when it comes to the regime of conducting business, the position of the state is independent of the share capital structure of the company in which it owns the golden share.

Therefore, performing activities of general interest by entrustment, differs from performing activities by enterprises established by the state for conducting activities and directly performing activities by the state administration, among other things, because these entities have the original legal right to perform certain activities of general interest, while the economic operators entrusted with performing this activity do not have such a right.

They will only be able to authoritatively step toward users, citizens and legal entities only in case when they have been entrusted by the competent authorities with the performance of such tasks in accordance with the law and the contract. 


\section{The basis for performance of general interest by confidence}

There are many different forms of private sector involvement in performing activities of general interest, and the most common classifications are based on the criteria of investment, ownership of capital and equipment and responsibility (risk). Observing the process of changes in almost all countries, especially countries in transition, private sector involvement in areas of state competence is in an upward trend.

The way that private sector participates varies from country to country and from industry to industry. In the practice of other countries of general interest, the most common forms of entrustment are the activities of general interest, concessions, leasing, BOT, joint venture and service contract.

The choice of any form of private equity participation will be determined by the state or a lower unit of territorial administration, depending on the legislation of the country, of course choosing the most appropriate form according to its capabilities and above all, according to the needs of the beneficiaries, for which it is responsible.

However, regardless of the form of cooperation with a private partner, it should be kept in mind that in our country, the practice of quality contracting is quite underdeveloped, and also arbitration and protection in cases of default or deviation from the contractual obligations are quite weak. Conscientious private partner, with successful and long business, precision of the contract and prescribed contractual guarantees, are in activities of general interest, extremely important, which is why they should be an integral part of the contract, because without them it is not possible to provide the necessary reliability of contractual clauses.

The risks, especially in the part of concluding international treaties, are great, especially in large multinational companies. It is of paramount importance to the State that the partner who has undertaken the obligation to carry out an activity of general interest fulfills that obligation. In case of any deviation, it is necessary to have reliable guarantees, but also a realistic alternative. On the other hand, serious problems can arise when a Contracting Party is unable to fully discharge its obligations under the contract.

\section{Specifities of business entities submitting business of general interest}

State-owned enterprises should be de lege ferenda treated as an economic term for all enterprises whose sole or majority founder is a state, RS, AP or local government unit, in which capital from public sources is invested - budgetary funds. Such enterprises are solely with one founder or with one of the majority founders, which are by their nature, public entities and which invest in public funds for the establishment and operation of such enterprises. Such companies are established as public companies (including public utility companies in Serbia) and as equity companies - joint stock companies and limited liability companies. The economic policies that such companies should consistently implement should primarily be based on a well-designed development and investment concept that, in addition of improving economic efficiency in complete 
operations, production processes, plants and facilities to reduce energy costs and increase the company's competitiveness, implies a reduction of emission of gases in greenhouse and conservation of natural resources.

Competence for the performance of activities of general interest by state-owned enterprises implies the original rights defined by law and, by contrast, obligations relating to the performance of activities of general interest.

The founder of the company is obliged to provide a structure through which the goals of the company will be set, to define the means for achieving those goals and monitoring the performance, and at the same time, appropriate stimulation to the executives and board members in the company, in order to pursue the goals that are in the interest of the company and the owners of the capital, and enable effective supervision to ensure business continuity.

The main common goal of any legal entity, whether it is a company with different forms of ownership or a company organized as a joint stock company, is to ensure business continuity. The goal of non-profit activities is to satisfy the interests of the wider community. Although the goals that affect the essence of their business are different, all legal entities at the core of their existence have a need for continuity in their work and duration for an indefinite period.

In theory and practice, it is indisputable that an enterprise has a lucrative purpose, it is established for the purpose of acquiring, disposing and distributing profits among the members of the enterprise, with the preliminary payment of obligations to all creditors and other persons interested in the business of the enterprise. Therefore, with the exception of non-profitable legal entities, the company has a legal presumption of commerciality. In the economic literature, an enterprise is considered to be the basic economic cell of society and, above all, of the economy.

Therefore, all economists point out as the most important two basic aspects of each company: organizational aspect and target aspect - profit.

According to the well-known principles of corporate governance, adopted in most countries, the achievement of the company's objective function - profit maximization, respectively, the value of the company, is an imperative of every company.

It is well-known that the main goals of the modern corporation and its managers today are: a) a safe increasing return on investment, a safe and long-term inflow of cash, as the most liquid assets and increased earnings; b) high management income with the possibility of valuable annual bonuses; v) the increasing growth and expansion of the corporation in order to expand its business and expand its market; g) good competitive position. These goals are in a causal consequence, and so we come to the highest goal of the corporation and its management, which strives for a steady increase in profits, because this is how the safe life of the corporation is maintained (Rajnović, 2013). Profit is an means for distributing periodic and annual corporate profits to corporate owners through dividends, rewards to management for achieved results, because it is necessary to establish a certain relationship a number of factors of the management 
and the processes within the board, that willhavepositive businessresults in order to effectively and efficiently perform all of its functions (Ljubojević \& Dašić, 2018) and, of course, it is partly accumulated for investing in new projects, or preserving for corporate survival and overcoming problems in case of all-weather or occasional cyclical developments in the world (Rajnović \& Bukvić, 2017).

Everywhere in the world, companies perform a very important function for every state and society as a whole, they have a great influence on the social community, so they have an obligation to act in the general social interest, respecting the good rules of social responsible business.

With the law that governing the business of public companies is stipulated that the founder "shall be obliged to ensure that the activity of general interest is carried on continuously" (Law on Public Enterprises).

In order to gain mentioned condition, the founder must provide the business entity with a mode of financing the business. In the case of a non-profit activity, the founder is obliged to provide financing for the performance of the activity in complete. In the case of a business entity that is performing a profitable business, the founder and business entities should fully comply in accordance with market conditions.

According to the provisions of domestic law, there are contours which make a difference between a state-owned enterprise engaged in an activity of general interest relative to all other companies, whether state-owned, privately owned or mixed-ownership. The law stipulates that every state-owned enterprise perform an activity of general interest:

- based on the law and the founding act,

- has a revenue base provided,

- has an obligation to carry out the activity on a continuous basis,

- $\quad$ operates for profit,

- $\quad$ is obliged to transfer $50 \%$ of the profits to the budget of the Republic of Serbia, autonomous provinces or local self-government units, according to the final account for the previous year,

- cannot perform additional activities without the consent of the founder,

- $\quad$ is under the strict supervision of the founder, respectively, the state and in the case where the founder is another public company or a state-owned capital company

- $\quad$ in the case of disruption of public enterprise, the Government, the competent authority of an autonomous province or local self-government unit, shall take measures to ensure the conditions for the undisturbed performance of activities of general interest, unless by the founding act and the law is determined differently, but in any case ,the provision of services of general interest must be ensured to the service users. 
The state, RS, an AP or a LSGU are the owners of several companies, capital companies that are likely going to be privatized in the near future, which companies actually carry out business of general interest, but get them by tendering with contracting authorities public companies and other state-owned capital companies established for the purpose of performing their activities of general interest. These companies, although in form the same as capital companies that carry out activities of general interest, perform this activity in practice as sole or additional activity, but are substantially different from enterprises established for this purpose, because they do not have the original basis of their activity, they do not have a basis of income other than if they do not obtain a job in the market, they are not obliged to perform activities of general interest on a continuous basis (except for a contractual obligation when / if they get a job in the public procurement procedure) and are not subject to the obligations prescribed by the LPE. In these companies, the state as the owner acts as a civil legal entity and has property and personal rights and obligations prescribed by the Companies Act.

It is frequently stated in the founding acts of these companies that they also perform an activity of general interest that they actually perform, but this does not mean that they are entrusted with performing water activities within the meaning of the LPE provisions. Each company must have a registered predominant activity specified in the founding act, but it can perform all other activities except those for which the law prescribes the issuance of a special permit, whether or not they are specified in the founding act.

In addition, with the law that governing the legal status of public companies is prescribed that a state (except city) cannot establish another public company or a capital company for performing the same business of general interest for which already exists a previously established company.

For example, the Public Company Elektroprivreda, was established for the purpose of carrying out the activity of electricity production (from the state was granted the right to use and manage the resource, water, coal, etc.) and from that it exists (by selling its product - electricity to users), good or bad depending on the management's ability to organize and manage the business, the Public Company Elektromreža (a subsidiary of JP Elektroprivreda) was established to perform the activity of electricity transfer and it exists from income, Telekom Srbija ad is founded for the provision of telecom services, sale of services and it exits from the income from its work, PC Srbijavode and Vojvodina are financed from the budget - therefore, all above mentioned and other companies have the legal basis of incorporation, the security of income provided by law and the founding act and therefore the obligation of continuous performing activities that are an indispensable condition of life and work of users, citizens and other persons.

\section{Supervision of the enterprise operating in the general interest}

One of the most sensitive and significant issues of business of companies, public enterprises and capital companies, which are in the exclusive or majority state ownership 
in the Republic of Serbia (including the ownership of narrow territorial units) and in European countries, which are performing activities of general interest, is the issue of control of their work. The basic function of this control is to ensure their functioning as an entity of business (commercial) law, and not as an entity of administrative law (the state as the holder of domination rather than empire). As the management of these societies is increasingly moving towards a kind of "technocratism", it is understandable that the instruments of their control are being strengthened. These are various instruments of previous control (through giving consent of the competent state body to certain acts, decisions, tariff systems, election of the administration), control through a specially appointed supervisory board in Serbia (reviewing the annual report, annual accounting and proposals for profit distribution and reporting on the competent state authority) as well as the instruments of ex-post control (control by government, control by specially appointed verification committees, control by parliament), through the direct participation of representatives of the state in management and supervisory boards of these companies (as in some developed countries) and through the participation of representatives of service users and competent institutions in supervisory boards or other management bodies that supervise the work of the company (Punter, 1987).

The formation and evolution of a management model depends on the degree of development, as well as on the changes in the requirements of the business. The objective function of a functional model in an enterprise is to balance the role of business and function. A balanced functional management model implies the allocation of responsibilities, the business is responsible for the operating result, for achieving the business results and for the efficient management of the operational business of all functions, and the founder supplies it with the necessary resources and controls its operations (Haller, 1998). Business sets operational tasks in the ordinary course of business. Therefore, both, business and the state, should take into account the opinion of the latter and agree on everything.

\section{Case study in practice in area of water management}

The author has been researching the status of companies owned by the Republic of Serbia that have been performing water activities for decades, and for centuries, in accordance with the law which governing water activities, activities of general interest (Law on Water). In practice, the question has arisen whether these enterprises were established by the state for the purpose of conducting water activities, as activities of general interest, or are they state-owned enterprises engaged in conventional commercial activities for profit?

In the course of the research, the author has determined the facts regarding the history of the emergence of comanies engaged in water activities (water activities companies or water management companies: WAC), with the transformation initiated, the acts of the enterprise and especially the existence of attributes characteristic only of state enterprises for which it is unambiguously clear that they were established for performing activities of general interest: basis acquisition of the right to perform the 
activity, provided base of income and the existence of an obligation in continuous performance of activity.

Namely, until 2014. year, water utilities operated in the form of social enterprises. Since the privatization of social capital was tied to a deadline (end of 2015), in 2014. year the RS Government adopted a conclusion which took over the capital of the company so the change of legal form and ownership was entered in the register of companies at the end of 2015. year, on the basis of which the companies became $100 \%$ in the ownership of the state, the Republic of Serbia, and as it was planned, as a transitional phase of further reorganization that was planned at that time.

In analyzing the mentioned case, the author took into account a LPE provision that stipulates that in addition to public companies, the activity of general interest may be performed by a capital company whose sole owner is the Republic of Serbia, an autonomous province and a unit of local self-government, as well as other economic entities mentioned in the quoted article (Law on Public Enterprises). In practice have appeared doubts whether water utilities are capital companies that fall under the aforementioned legal provision. According to the author, the ministry in charge of the economy, without deeper analysis, has taken the opinion that water management companies were established for the purpose of conducting water activities as activities of general interest and thus have an obligation to operate in accordance with the LPE.

On the basis of the above facts, the author concluded that water management companies are not enterprises which, based on takeovering capital by the RS and the actual performance of water activities, have become undertakings of general interest in accordance with the LPE, for the following reasons:

- Articles 23 and 150 - 152 of the Water Law stipulate that water activities, activitie of general interest, is performed by two public companies of JP Srbijavode and JP Water of Vojvodina, as well as the financing of the operations of these companies is carried out from the founders budget, which is prescribed in the founding acts of companies, which are established for the purpose of performing activities of the general interest. In order to conduct water activities in the manner of public companies, it is not sufficient for the water management companies to meet the requirements of the LPE. Water management companies can only start the water business if they succeed in the tender with contracting authorities - public companies to get a job in competition with all other private companies. Outside of this, Water management companies have absolutely no other formal powers, rights and obligations to engage in water activities.

- In addition, with the founding acts of the WAC, in accordance with the provisions of the Companies Act, is prescribed the predominant activity of the WAC - 4291 - construction of hydraulic structures. The fact that in the acts is stated that WAC perform water activities, also does not mean that they are entrusted with performing water activities within the meaning of the aforementioned LPE provisions, which entails performing activities of general 
interest under the law itself as a public company or by contract. Each company must have a registered predominant activity specified in the founding act, but it can perform all other activities except those for which the law prescribes the issuance of a special permit (Law on Public Enterprises), whether or not they are specified in the founding act.

- In addition, article 14 of the LPE stipulates that the founder can not establish another public company or a capital company referred to in article 3 , paragraph 2, items 1 and 2 of the LPE to perform the same activity of general interest, which means that the water activity performed by JP Srbijavoda excludes the possibility of performing the same activity by the WAC under the conditions under which the water activities are performed by public companies, respectively the WAC were not established for the purpose of performing activities of general interest. In this case, the essential difference between the WAC and the public companies is clearly specified.

- WAC get part of the job (if they get it) by participating in the tender of contracting entities - public companies, which is why they do not have a secure basis of income, except on the basis of a contract with a public company, again if they get a job in the public procurement procedure, and because of that they cannot have the obligation to carry on business on a continuous basis, with the exception of the obligation under a contract with a public company.

- WAC cannot perform water business until they have acquired that right to public procurement, because, under the Water Act, the original right in performing this activity belongs to public companies.

- This is the essential difference between the WAC and other companies which perform an activity of general interest referred to in Article 3 of the LPE therefore, 1) the manner of obtaining the right to perform the activity, 2) the basis of financing, and 3) the obligation of continuously performance of activity.

Obviously, the right creator did not intend the LPE to create contradictory, logically contradictory legal provisions. Logical interpretation aims to avoid logical contradictions within a particular legal norm. However, the resolution of logical contradictions extends to larger units, groups of legal norms, entire legal acts, and ultimately to the whole legal system. The legal system is considered to be one logical non-contradictory whole, so that certain legal regulations must be interpreted in accordance with that whole (Mitrović, 2017).

Argumentum a contrario or interpretation to the contrary, implies that to all cases not covered by a norm, the opposite norm applies, e.g. if the RS established JP Srbijavode to perform water activity (and in addition to the provision of the LPP, no other company engaged in the same activity can't be established), it is concluded that the RS did not establish a WAC for the purpose of performing water activity. In this regard, the author has determined, by linguistic and logical interpretation of the law, as follows: 
- firstly, by the legal norm of the Water Law, it was unambiguously interpreted by linguistic interpretation that the RS established JP Srbijavode for the purpose of performing water activities, i.e. the aforementioned standard covers PE Srbijavode, but not WAC, and Article 14 of the LPP clearly and unequivocally stipulates that Republic of Serbia cannot establish another company to perform the same activity,

- secondly, that standard establishes that the WAC are not covered by the aforementioned provision of the Water Act, so their case is different from the case of JP Srbijavode, and

- thirdly, it is concluded that the norm of Article 23 of the Water Law and Article 14 of the LPP cannot be applied to cases which do not include, respectively, to a case that is a legal void, of water utilities, another norm should be applied, contrary to the mentioned norm. On the basis of the above, it is concluded that the WAC were not established for the purpose of performing water activities as activities of general interest.

\section{Conclusion}

In economic entities carrying out activities of general interest, due to the importance of activities for users, civil and legal entities on the one hand and rational management of budget funds intended for those activities, providing an adequate system of monitoring and analysis of spending of funds, as well as an adequate system of training of employees, information at all levels can be provided to support the operational management of systems and to make adequate management decisions.

Business development policy and modernization of all business segments should focus on the application of world best practices in this area and regulation of the level of all costs, with a clear distinction between economic entities which perform activities of general interest based on original law, which have clear specificities, from those who do not actually engage in this activity and who should operate fully on the market, without any government interference in their business, except as the owner of the capital.In such a case, the state would be less occupied by a number of owner-occupied economic entities that do not carry out the original activity of general interest, and more focused on its other activities and process planning necessary to establish the overall scope of the project related to economic entities of general interests, until their eventual privatization, define and refine the goals and develop a plan for achieving the goals, continuously develop a management plan as well as monitor, control and review the progress of business entities, comparison of predicted and achieved performance, analysis of deviations, initiation of appropriate changes, etc. (Project Management Institute PMI, 2013).

In the last few decades, there has been a significant increase in the participation of private property in performing activities of general interest in the world, respectively, an increase in the importance of private capital in that activity. This process is universal, 
so that in addition to developed countries, it has also affected countries in evolving, respectively countries in transition.

Since there are also significant differences in the economic nature of various activities of general interest, it is not possible to define a universally optimal proprietary and organizational solution in this activities.

Valuation of solutions based on the introduction of private property, an activity of general interest in Serbia, must be performed at the level of individual regions and individual activities. When defining the optimal solutions for each industry or area in Serbia, other factors should be taken into account, such as the size of the region, the specifics of the services provided to customers, then the size and characteristics of the demand for services, the need for new investments.

\section{Acknowledgement}

This article is the result of Ljiljana Rajnovic research financed by Ministry of Education, Science and Technology Development of the Republic of Serbia.

\section{Conflict of interests}

The authors declare no conflict of interest.

\section{References}

1. Berber, N. \& Slavić, A. \& Aleksić, M. (2019) The Relationship Between Corporate Social Responsibility and Corporate Governance, Society of Economists, Ekonomika, Niš, 1-13.

2. Cobrett, A. (2008): Corporate Social Responsibility - Do We Have Good Cause to be Sceptical About it? Griffith Law Review, 17(1), 413-432.

3. Company Law (Official Gazette of RS, No. 36/2011 and 99/2011, 83/2014 - second law, 5/2015, 44/2018 i 95/2018).

4. Decree of Fundamentals of Water Management of the Republic of Serbia (Official Gazette of RS, No. 11/2002).

5. Dufau. P. (1973): Les entreprises publiques, I'Actualite Juridique Paris, 54-118.

6. Dusmanescu, D., Andrei, J., \& Subic, J. (2014). Scenario for implementation of renewable energy sources in Romania. Procedia Economics and Finance, 8, 300-305.

7. Gower, L. (1992): Principles of Modern Company law, Sweet \& Maxwell, London, 5-7.

8. Haller, M. (1998): Private, Public and Common Ownership, Analyze \& Critic, $\mathrm{http} / /$ : analyze-und-kritik.net

9. Hamel, J., \& Lagarde, G., \& Jauffret, A., (1980): Droit commercial, II, Paris, 731734, 771-776. 
10. Ljubojević, G., \& Dašić, G. (2018). Boards attributes and their implications on decision-making process. Menadžment u hotelijerstvu i turizmu/ Hotel and Tourism Management, 6(1), 19-29.

11. Mitrović, D. (2017): Osnovi prava, Singidumun University, Belgrade, 208, (in English: Mitrović, D. (2017): Basics of law, Singidumun University, Belgrade, 208).

12. Law on Public Enterprises (Official Gazette of RS, No. 15/2016).

13. Law on Waters (Official Gazette of RS No. 30/2010, 93/2012, 101/2016, 952018 and 95/2018 - other law).

14. Punter, D. (1987/88): Rukovođenje i kontrola nad javnim preduzećem, Bulletin of the Law Faculty of Kragujevac, 21-29, (in English: Punter, D. (1987/88): Management and control of a public enterprise, Bulletin of the Law Faculty of Kragujevac, 21-29).

15. Project Management Institute PMI (2013). A Guide to the Project Management Body of Knowledge (PMBOK@Guide) Newton Square.

16. Rajnović, Lj. (2013): Socially responsible business in the function of improving the economic environment in the Republic of Serbia (on Serbian). Association of economists of Belgrade, Belgrade.

17. Rajnović, Lj. \& Bukvić, R. (2017): Korporativno upravljanje kao deo poslovne strategije kompanija, Institut za ekonomiku poljoprivrede Beograd. (in English: Rajnović, Lj. \& Bukvić, R. (2017) Corporate governance as part of the company's business strategy of companies, Institute of Agricultural Economics, Belgrade).

18. Vasilescu, I., Cicea, C., Popescu, G., \& Andrei, J. (2010). A new methodology for improving the allocation of crops cost production in Romania. Journal of Food, Agriculture and Environment, 8(2), 839-842.

19. Vasiljević, M. (1999): Domestic and Comprehen'sive Law Companies, Association of Lawyers in the Economy of FR Yugoslavia, CIP 347.22, 416 - 417. 